IRA-International Journal of Education \& Multidisciplinary Studies

ISSN 2455-2526; Vol.08, Issue 01 (July 2017)

Pg. no. $94-113$

Institute of Research Advances

http://research-advances.org/index.php/IJEMS

\title{
Perceived Social Support, Career Aspiration and School Engagement of First Generation Learners and Second Generation Learners
}

\author{
Nandini Sanyal $^{1 \#}$, SushmitaTandon ${ }^{2}$, Tina Fernandes ${ }^{3}$ \\ ${ }^{1}$ Asst. Prof., Dept. of Psychology, St. Francis College for Women, Begumpet, Hyderabad - \\ 500016, India. \\ ${ }^{2}$ Post Graduate Student, St. Francis College for Women, Begumpet, Hyderabad - 500016, India. \\ ${ }^{3}$ Retd Head, Dept. of Psychology, St. Francis College for Women, Begumpet, Hyderabad - \\ 500016, India.
}

\# corresponding author.

Type of Review: Peer Reviewed.

DOI: http://dx.doi.org/10.21013/jems.v8.n1.p10

\section{How to cite this paper:}

Sanyal, N., Tandon, S., Fernandes, T. (2017). Perceived Social Support, Career Aspiration and School Engagement of First Generation Learners and Second Generation Learners. IRA International Journal of Education and Multidisciplinary Studies (ISSN 2455-2526), 8(1), 94-113. doi: http://dx.doi.org/10.21013/jems.v8.n1.p10

(C) Institute of Research Advances.

\section{(cc)) BY-NC}

This work is licensed under a Creative Commons Attribution-Non Commercial 4.0 International License subject to proper citation to the publication source of the work.

Disclaimer: The scholarly papers as reviewed and published by the Institute of Research Advances (IRA) are the views and opinions of their respective authors and are not the views or opinions of the IRA. The IRA disclaims of any harm or loss caused due to the published content to any party.

Institute of Research Advances is an institutional publisher member of Publishers Inter Linking Association Inc. (PILA-CrossRef), USA. The institute is an institutional signatory to the Budapest Open Access Initiative, Hungary advocating the open access of scientific and scholarly knowledge. The Institute is a registered content provider under Open Access Initiative Protocol for Metadata Harvesting (OAI-PMH).

The journal is indexed \& included in WorldCat Discovery Service (USA), CrossRef Metadata Search (USA), WorldCat (USA), OCLC (USA), Open J-Gate (India), EZB (Germany) Scilit (Switzerland), Airiti (China), Bielefeld Academic Search Engine (BASE) of Bielefeld University, Germany, PKP Index of Simon Fraser University, Canada. 


\begin{abstract}
The term 'first generation learners' refers to students who are first ones in their entire family to go to school and receive an education. The present study is quantitative study which adopts a factorial design in which first-and second generation learners and gender are treated as the Independent Variables, and perceived social support and its dimensions, career aspirations and its dimensions and student school engagement and its dimensions are considered as Dependent Variables. The present study also adopts a correlational design to determine whether perceived social support and career aspirations predict student school engagement in first and second generation learners (girls and boys). Non-probability purposive sampling technique was used to select a sample of 150 first generation learners and 150 second generation learners from Hyderabad. Results showed that there were significant differences between the two groups with respect to career aspirations, educational aspirations and leadership aspirations. Significant gender differences were observed with respect to belonging support and educational aspirations. Stepwise regression analyses showed that perceived social support and career aspirations and their dimensions are predictors of student school engagement and its dimensions in both first and second generation learners. Such results highlight the importance of formulating policies to improve the status of first generation learners, taking into consideration their economic status and other cultural and psychological aspects. Workshops for educationalists and school counsellors who may work closely with first-generation students should address issues that may be particularly relevant to this group.
\end{abstract}

Keywords: first and second generation learners, Perceived social support, career aspirations and students school engagement

\title{
INTRODUCTION
}

In the 21ST century the researchers have focused massively on adolescence as they are going to be the pioneers of the future. The researchers have also tried to find whether their generation (i.e. first generation learners or non-first generation learners) influences various aspects such as perceived social support, career aspirations and school engagement. In the past few years, there is growth in admissions of first generation learners with respect to schooling, or higher education. All practice in education involves commitments, assumptions and goals that demand philosophical scrutiny. The absence of such scrutiny has a direct implication on the effectiveness of the practitioner (The Hindu, January 20 2015). Students' involvement in education may be influenced by perceived social support, career aspirations and school engagement. In today's world there is substantial interest in how much support is given to adolescents from their family, peers and school to achieve their goals or full fill their dreams. Social support refers to an interaction, person, or relationship (Veiel \& Bauman, 1992). Social support is defined two ways: firstly, as information which affords the perception of being cared for, esteemed and valued by members of one's social network (Dubow, Tisak,Causey,Hryshko, \& Reid, 1991; Dubow \& Ullman, 1989), and secondly, as the availability of people on whom we can rely, and who let us know that we are cared for and valued(Sarasin, Levine, Basham \& Sarason, 1983).

Striplin (1999) found that families of first generation learners sometimes discourage them from going to college, this can lead to alienation of family support. Many students have identified parents as being vital sources who provide support (Gloria, 1997; Kenny et al., 2003) and encouragement (Fisher \& Padmawidjaja, 1999), however, other sources of support have also been recognized. For instance, extended family members, friends, teachers, and counsellors have been listed as important agents that influence both academics and career aspirations (Bullington \& Arbona, 2001; McWhirter, Hackett, \& Bandalos, 1998; Phillips, Christopher-Sisk, \& Gravino, 2001).In another study Rothen et.al (2011) reported that adolescents who are encouraged to do well by their parents were more than twice as likely to aspire to remain in education.

Aspirations reflect a student's conceptualization of his or her future self, and likely influence choices, direct goal setting, and guide behaviour (Bandura,2001). A student's aspirations are comprised are of their hopes and goals for their future (Sirin, Diemer, Jackson, Gonsalves \& Howell, 2004).Career aspirations are defined as long-term individual work related goals (VandenBos, 2007). For this study, career aspirations have been defined as a concept similar to aspirations in general, educational aspirations, leadership aspirations and achievement aspirations. 
According to McCarron (2012), first generation college students have paths to higher education much different than their non-first generation peers. In a study of 103 first generation students, He examined the contributing factors of persistence and aspirations in the realm of education attainment of first generation students. Through his results, he discovered that high pre-college aspirations and family support are vital in the persistence of educational attainment and prevention of burnout for first generation students. Based on this research, it could be possible that high pre-college aspirations and family support linger during the undergraduate years and are key in shaping first generation students' aspirations to pursue advanced degrees (McCarron, 2012).

Students' aspirations appear to be related to parents' educational levels. The more education parents have the higher students' aspirations (Penrose, 2002). First-generation students may encounter a cultural conflict between home and college community (Thayer, 2000).In a study Veiga et.al (2014) revealed that there is a positive relation between student school engagement and academic aspirations. School engagement is a meta-construct that includes behavioural, emotional, and cognitive engagement (Fredricks et al., 2004). Although there are large individual bodies of literature on behavioural (i.e., time on task), emotional (i.e., interest and value), and cognitive engagement (i.e., self-regulation and learning strategies), what makes engagement unique is its potential as a multidimensional or "meta"-construct that includes these three dimensions. Behavioural engagement draws on the idea of participation and includes involvement in academic, social, or extracurricular activities and is considered crucial for achieving positive academic outcomes and preventing dropping out (Connell \& Wellborn, 1991; Finn, 1989).

Emotional engagement focuses on the extent of positive (and negative) reactions to teachers, classmates, academics, or school. Others conceptualize emotional engagement as identification with the school, which includes belonging, or a feeling of being important to the school, and valuing, or an appreciation of success in school-related outcomes (Finn, 1989; Voelkl, 1997). Positive emotional engagement is presumed to create student ties to the institution and influence their willingness to do the work (Connell \& Wellborn, 1991; Finn, 1989). Cognitive engagement is defined as student's level of investment in learning. It includes being thoughtful, strategic, and willing to exert the necessary effort for comprehension of complex ideas or mastery of difficult skills (Corno \& Mandinach, 1983; Fredricks et al., 2004; Meece, Blumenfeld\&Hoyle,1988).

Terenzini et.al (1996) found that first generation learners have lower level of school engagement and they mostly come from low socio economic status. In a study conducted by Pike and Kuh (2005) in Africa on 1,127 firstyear students at a variety of four-year colleges and universities found that first-generation students tended to be less engaged and gained less from college than their counterparts with college-educated parents did. These differences were primarily due to first-generation students having lower educational aspirations and living off campus.

Of 1.3 million first-time freshmen who took the Scholastic Aptitude Test (SAT) in 2002, it was found that over 28 percent were first-generation students in India (Ishitani, 2003). The experience of first-generation students varies depending on their income background and their ethnicity. Those from middle income backgrounds find adjustment to college less difficult than first-generation students from ethnic minority or low-income backgrounds (Thayer, 2000). Similarly, Horn and Nunez (2000) reported that first-generation students were more likely to be ethnic minorities than non-first-generation students. In Tamil Nadu it was found that one-third of candidates who got admitted in college on the first two days of the single window counselling process for admission were found to be first-generation graduates. Of the 5,333 candidates who had their pick of technical courses in the state, 1,699 will be the first in their families to enter college. (Times of India, July 10, 2014).

Educational consultant Gopalakrishnan (2015) said state schemes benefitting first-generation graduates, like the 50\% tuition fee waiver, are encouraging more parents to send their children to college. "The numbers will keep increasing in the coming years," she said. The schemes have also helped increase the gross enrolment ratio in the state to 19\% compared to the national average of around 15\%.(The Hindu, January 20, 2015). The experience of first-generation students varies depending on their income background and their ethnicity. Those from middle income backgrounds find adjustment to college less difficult than first-generation students from ethnic minority or low-income backgrounds (Thayer, 2000).

From the studies given above we can say that there is difference among first and second generation learners with respect to various aspects such as self- efficacy, motivation, goals, academic preparation, self-regulation, aspirations, perceived social support and school engagement e.tc. Currently, aspirations, social support and school engagement is very important aspect for students especially when they are adolescents. Their generation (i.e first or 
second generation learners) may have an effect on these aspects. Benefits of aspirations, perceived social support and school engagement and differences among first and second generation learners makes it worthy for further investigation. Based on the contexts of the above studies, the following objectives and were outlined.

\section{Objectives:}

- To study whether there is a difference between first generation learners and second generation learners with respect to perceived social support and its dimensions (viz., appraisal support, tangible assets support and belonging support), career aspirations and its dimensions (viz., educational aspirations, achievement aspirations and leadership aspiration) and student school engagement and its dimensions (viz., behavioural engagement, emotional engagement and cognitive engagement).

- To observe whether there is a gender difference between first generation learners and second generation learners with respect to perceived social support and its dimensions (viz., appraisal support, tangible assets support and belonging support) career aspirations and its dimensions (viz., educational aspirations, achievement aspirations and leadership aspiration), and student school engagement and its dimensions (viz., behavioural engagement, emotional engagement and cognitive engagement). To study whether perceived social support and its dimensions (viz., appraisal support, tangible assets support and belonging support) and career aspirations and its dimensions (viz., educational aspiration, achievement aspirations and leadership aspiration), predict student school engagement and its dimensions (viz., behavioural engagement, emotional engagement and cognitive engagement) in first generation learners.

- To study whether perceived social support and its dimensions (viz., appraisal support, tangible assets support and belonging support) and career aspirations and its dimensions (viz., educational aspirations, achievement aspirations and leadership aspiration),predict student school engagement and its dimensions (viz., behavioural engagement, emotional engagement and cognitive engagement) in second generation learners.

\section{Method}

\section{Research Design}

The present study is a quantitative study in which first-and second generation learners and gender are treated as the Independent Variables, and perceived social support and its dimensions (appraisal support, tangible assets support and belonging support), career aspirations and its dimensions (educational aspirations, achievement aspirations and leadership aspiration) and student school engagement and its dimensions ( behavioural engagement, emotional engagement and cognitive engagement) are considered as Dependent Variables. The present study also adopts a correlational design to determine whether perceived social support and career aspirations predict student school engagement in first and second generation learners.

\section{Sample}

Non-probability purposive sampling method was used to select a sample of 300 students. Out of the total sample 150 were first generation learners ( 75 boys and 75 girls) and 150 were second generation learners ( 75 boys and 75 girls) from low socio economic status.

Inclusion criteria

First generation learners -

1. Students whose parents were not educated were included.

2. Students should be within 13-16years of age.

3. Students living in Hyderabad city were included.

4. Students with parents who had their monthly income within 12,000 were included.

5. The students of Telugu and English medium were included.

$\underline{\text { Second generation learners }-}$

1. The student's parent's education qualification had to be between $5^{\text {th }}-10^{\text {th }}$ standard.

2. Students should be within 13-16years of age.

3. Students living in Hyderabad city were included.

4. Students with parents who had their monthly income within 12,000 were included. 
5. The students of Telugu and English medium were included.

Exclusion criteria-

1. Students pursuing distance education were excluded.

2. Students staying away from their parents were excluded.

3. Students who were orphans or had a single parent were excluded.

4. Students below $8^{\text {th }}$ grade and above $10^{\text {th }}$ grade were excluded.

5. Students with history of any chronic physical or psychological disorder were excluded.

6. Students with any family history of any chronic physical or psychological disorder of the family members.

\section{Instruments}

Four questionnaires were used in this research. They were:

\section{Information Schedule}

Participants were asked to provide their gender, age, education, family information (Parents' education, socioeconomic status, number of siblings), physical and psychological health of the respondents as well as their family members, and the like in writing, on the Information Schedule.

\section{Interpersonal Support Evaluation List (ISEL) -12 item shortened version}

This scale was developed by Cohen, Mermelstein, Kamarck, \& Hoberman, 1985).ISEL is a 12-item measure of perceptions of social support. These dimensions are, Appraisal Support (AP), Tangible Assets Support (TA ) and Belonging Support (BE). Appraisal support contains item 2, item 4, item 6 and item 11. Belonging support contains item 1, item 5, item 7 and item 9.Tangible support contains item 3, item 8, item 10 and item.

Each dimension is measured by 4 items on a 4-point scale ranging from "Definitely True" to "Definitely False". The ISEL-12 is derived from the long form of the ISEL and contains 12 items which assess the perceived availability of social support on a four-point scale ranging from "definitely false" to "definitely true." All items are summed to yield a total score (scores range 0-36). Also the scale describes the appraisal, belonging, and tangible subscales (scores range 0-12) comprised of four items each. Some of the items are reverse scored. The reverse scored items are item 1, item 2, item 7, item 8, item 11 and 12. All scores are kept continuous. Higher scores indicate Higher Appraisal/ Belonging / Tangible Support. Cronbach's alphas for the ISEL-12 total score were all above 0.70 in the full sample. Convergent validity analyses suggested that the ISEL-12 scores were positively related to social network integration and life engagement, and inversely related to perceived stress and negative effect.

\section{Career Aspiration Scale - Revised (CASR)}

This scale was developed by Gregor \& O'Brien, (2015). The newly translated K-CASR was used to measure career aspirations. The scale consists of 24 items. The CASR consists of three subscales including leadership, educational, and achievement aspirations (Gregor \& O'Brien, 2015). Achievement Aspiration consists of item 3 , item 8 , item 9 , item 13 , item 17 , item 20 , item 21 and item 22 . Item 1 , item 2 , item 4 , item 5 , item 7 , item 12, item 15, and item 24 belong to the leadership aspirations. Educational Aspiration contains item 6, item 10, item 11, item 14, item 16, item 18, and item 19. Reverse score items are 2, item 4, item 12, item 20 and item 22 so the responses are changed in the following way: $0=4,1=3,2=2,3=1,4=0$. The items are rated for was on a 5-point Likert Scale - 0 (not at all true of me) to 4 (very true of me). Scores for item are summed to get the total score for each subscale. Higher scores indicate higher aspirations in each domain (achievement, leadership, education). The scores on the three subscales may be added to get the total score on career aspirations. The Cronbach's $\alpha$ coefficient ranged from 0.71 to 0.88 . (Gregor \& O'Brien, 2015).

\section{School engagement scale-(SES)}

This scale was developed by Fredericks, Blumenfeld, Friedel and Paris (2005). It consists of 15 items. This scale was developed to measure behavioural, emotional, and cognitive aspects of student school engagement in elementary school students. Behavioural engagement items are item 1, item 2, item 3, and item 4. Emotional engagement items are item 5, item 6 , item 7 , item 8 , item 9, and item 10. Cognitive engagement items are item 11, item 12, item 13, item 14, and item 15. Item 2, item 4, and item 6 are reversed score. Participants are required to rate the responses on a likert scale ranging from 1 to $5(1=$ never, $5=$ all of the time, or $1=$ not at all true, $5=$ very true $)$. 
Higher scores reflect higher levels of engagement. The Coefficient alpha ranged from .72 to .86 . It has a good face validity, adequate internal consistency, and adequate predictive validity.

\section{RESULTS}

Table 1 - Results of Two-Way ANOVA and descriptive statistics with dependent variables perceived social support, career aspirations, student school engagement and their dimensions as Dependent variables and learners (viz., first and Second generation learners) and gender as independent variables. $(n=300)$.

\begin{tabular}{|c|c|c|c|c|c|c|c|}
\hline \multirow[t]{2}{*}{ Variables } & \multicolumn{2}{|c|}{ Learners } & \multicolumn{4}{|c|}{$\begin{array}{l}\text { Gender of } \\
\text { students }\end{array}$} & \multirow[t]{2}{*}{$\begin{array}{l}\text { Interaction effect } \\
\text { (Learners*Gender) }\end{array}$} \\
\hline & $\begin{array}{l}\text { First } \\
\text { generation } \\
\text { Mean } \\
\text { (S.D) }\end{array}$ & $\begin{array}{l}\text { Second } \\
\text { generation } \\
\text { Mean } \\
\text { (S.D) }\end{array}$ & $\mathrm{F}$ & $\begin{array}{l}\text { Boys } \\
\text { Mean } \\
\text { (S.D) }\end{array}$ & $\begin{array}{l}\text { Girls } \\
\text { Mean } \\
\text { (S.D) }\end{array}$ & $\mathrm{F}$ & \\
\hline $\begin{array}{c}\text { Perceived social } \\
\text { support }\end{array}$ & $\begin{array}{l}32.00 \\
(3.80)\end{array}$ & $\begin{array}{l}32.15 \\
(3.49)\end{array}$ & 0.123 & $\begin{array}{c}31.7 \\
(3.36)\end{array}$ & $\begin{array}{l}32.46 \\
(3.88)\end{array}$ & 3.302 & $3.90 *$ \\
\hline Appraisal support & $\begin{array}{l}11.15 \\
(2.22)\end{array}$ & $\begin{array}{l}10.80 \\
(2.17)\end{array}$ & 1.96 & $\begin{array}{l}11.15 \\
(2.22)\end{array}$ & $\begin{array}{l}10.80 \\
(2.17)\end{array}$ & 1.96 & 1.81 \\
\hline $\begin{array}{c}\text { Tangible assets } \\
\text { support }\end{array}$ & $\begin{array}{l}10.13 \\
(2.29)\end{array}$ & $\begin{array}{l}10.59 \\
(2.06)\end{array}$ & 3.39 & $\begin{array}{l}10.15 \\
(2.06)\end{array}$ & $\begin{array}{l}10.57 \\
(2.29)\end{array}$ & 2.83 & 3.01 \\
\hline Belonging support & $\begin{array}{l}10.72 \\
(2.21)\end{array}$ & $\begin{array}{l}10.76 \\
(2.14)\end{array}$ & 0.026 & $\begin{array}{l}10.39 \\
(2.08)\end{array}$ & $\begin{array}{l}11.08 \\
(2.21)\end{array}$ & $7.74 * *$ & 0.04 \\
\hline Career aspirations & $\begin{array}{l}66.12 \\
(10.22)\end{array}$ & $\begin{array}{c}68.92 \\
(10.03)\end{array}$ & $5.76 *$ & $\begin{array}{c}66.81 \\
(10.18)\end{array}$ & $\begin{array}{c}68.23 \\
(10.22)\end{array}$ & 1.47 & 1.88 \\
\hline $\begin{array}{c}\text { Educational } \\
\text { aspirations }\end{array}$ & $\begin{array}{l}22.27 \\
(4.13)\end{array}$ & $\begin{array}{l}23.51 \\
(3.69)\end{array}$ & $7.85 * *$ & $\begin{array}{l}22.27 \\
(3.69)\end{array}$ & $\begin{array}{l}23.51 \\
(4.13)\end{array}$ & $7.85 * *$ & $7.85 * *$ \\
\hline $\begin{array}{l}\text { Achievement } \\
\text { aspirations }\end{array}$ & $\begin{array}{l}22.56 \\
(5.02)\end{array}$ & $\begin{array}{l}22.85 \\
(4.66)\end{array}$ & 0.26 & $\begin{array}{l}22.56 \\
(4.66)\end{array}$ & $\begin{array}{l}22.85 \\
(5.02)\end{array}$ & 6.16 & 6.75 \\
\hline Leadership aspirations & $\begin{array}{l}21.29 \\
(5.69)\end{array}$ & $\begin{array}{l}22.57 \\
(5.19)\end{array}$ & $4.07 *$ & $\begin{array}{l}21.99 \\
(5.56)\end{array}$ & $\begin{array}{l}21.87 \\
(5.41)\end{array}$ & 0.03 & 0.01 \\
\hline $\begin{array}{l}\text { Student school } \\
\text { engagement }\end{array}$ & $\begin{array}{l}55.95 \\
(7.49)\end{array}$ & $\begin{array}{l}56.75 \\
(8.19)\end{array}$ & 0.822 & $\begin{array}{l}56.29 \\
(7.24)\end{array}$ & $\begin{array}{l}56.41 \\
(8.43)\end{array}$ & 0.01 & $18.67 * * *$ \\
\hline $\begin{array}{l}\text { Behavioural } \\
\text { engagement }\end{array}$ & $\begin{array}{l}14.54 \\
(3.44)\end{array}$ & $\begin{array}{l}15.07 \\
(2.96)\end{array}$ & 2.199 & $\begin{array}{l}14.56 \\
(3.11)\end{array}$ & $\begin{array}{l}15.05 \\
(3.31)\end{array}$ & 1.88 & $19.13 * * *$ \\
\hline $\begin{array}{l}\text { Emotional } \\
\text { engagement }\end{array}$ & $\begin{array}{l}23.76 \\
(3.55)\end{array}$ & $\begin{array}{l}23.57 \\
(3.62)\end{array}$ & 0.217 & $\begin{array}{l}23.75 \\
(3.61)\end{array}$ & $\begin{array}{l}23.58 \\
(3.56)\end{array}$ & 0.18 & $23.32 * * *$ \\
\hline Cognitive engagement & $\begin{array}{l}17.65 \\
(3.87)\end{array}$ & $\begin{array}{l}18.10 \\
(5.69)\end{array}$ & 0.646 & $\begin{array}{l}17.98 \\
(5.88)\end{array}$ & $\begin{array}{l}17.78 \\
(3.59)\end{array}$ & 0.12 & 0.29 \\
\hline
\end{tabular}

Note: ${ }^{*} \mathrm{p}<0.05,{ }^{* *} \mathrm{p}<0.01,{ }^{* * *} \mathrm{p}<0.001$.

Table 1 indicates that there is a significant difference between first and second generation learners with respect to career aspiration $(\mathrm{F}=5.76, \mathrm{p}<0.05)$. It is evident from the mean scores that the second generation learners scored higher $(\mathrm{M}=68.92, \mathrm{SD}=10.03)$ than the first generation learners $(\mathrm{M}=66.12, \mathrm{SD}=10.22)$ with respect to career aspirations. 
Moreover the results in Table 1 indicated that there is a significant difference between first generation learners and second generation learners with respect to the dimension of educational aspirations $(F=7.85, p<0.01)$. It is evident from the mean scores that second generation learners scored higher $(\mathrm{M}=23.51, \mathrm{SD}=3.69)$ than the first generation learners $(\mathrm{M}=22.27, \mathrm{SD}=4.13)$ with respect to educational aspirations.

Furthermore, the results indicated that there is a significant difference between first and second generation learners with respect to leadership aspirations $(\mathrm{F}=4.07, \mathrm{p}<0.05)$. It is evident from the mean scores that second generation learners scored higher $(M=22.57, S . D=5.19)$ than the first generation followed by first generation learners $(\mathrm{M}=21.29, \mathrm{~S} . \mathrm{D}=5.69)$ with respect to leadership aspirations.

Table 1 also revealed that there is no significant difference between first and second generation learners with respect to perceived social support, appraisal support, tangible assets support, belonging support ( $>0.05$ ). It also indicated that there is no significant difference between first and second generation learners with respect to the dimension of achievement aspirations ( $p>0.05$ ).Furthermore, table 1 indicated no significant differences between first generation learners and second generation learners with respect to student school engagement, behavioural engagement, emotional engagement, cognitive engagement ( $p>0.05$ ).

Moreover Table 1 also showed that there is a significant gender difference with respect to belonging support $(\mathrm{F}=7.74, \mathrm{p}<0.01)$. As is evident from the mean scores, girls are higher $(\mathrm{M}=11.08, \mathrm{~S} . \mathrm{D}=2.21)$ than boys $(\mathrm{M}=10.39$, S.D $=2.08)$ with respect to belonging support.

Moreover, Table 1 indicated that there is a significant gender difference in educational aspirations $(\mathrm{F}=7.85$, $\mathrm{p}<0.01)$. As is evident from the mean scores, girls are higher $(\mathrm{M}=11.08, \mathrm{~S} . \mathrm{D}=4.13)$ than boys $(\mathrm{M}=10.39, \mathrm{~S} . \mathrm{D}=3.69)$ with respect to educational aspirations.

However, Table 1 indicated no significant gender differences with respect to perceived social support, appraisal support, tangible assets support ,career aspirations , achievement aspirations, leadership aspirations, student school engagement, behavioural engagement, emotional engagement and cognitive engagement $(p>0.05)$.

Table 1 showed significant interaction between learners(viz., first generation learners and second generation learners) and gender with respect to perceived social support ( $\mathrm{F}=3.90, \mathrm{p}<0.05)$. The graphical representation of this result is seen in figure 1 given below.

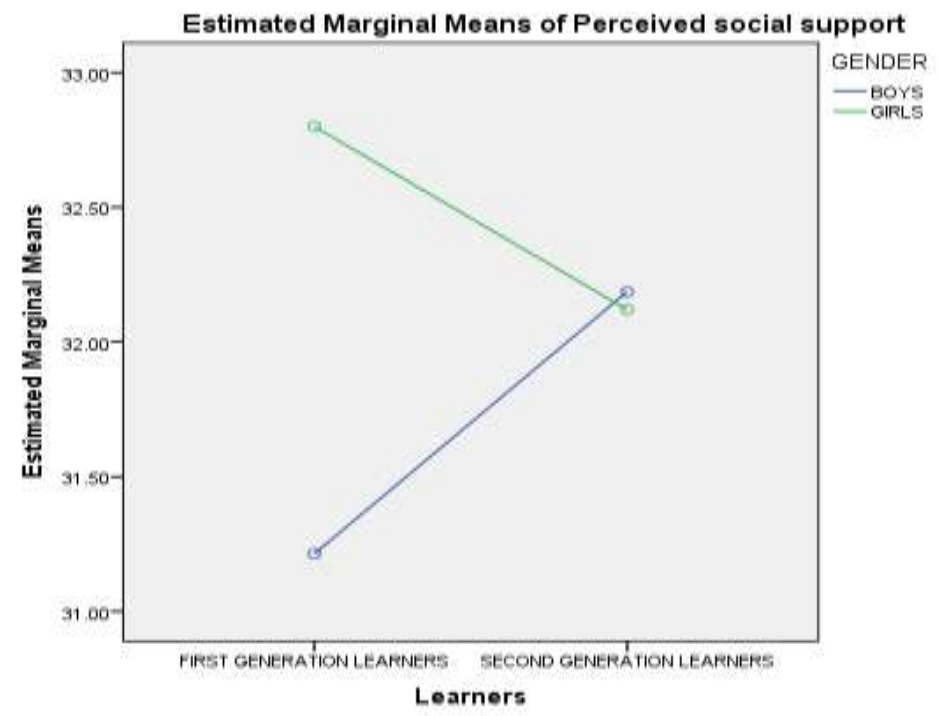

Figure 1 - Line graph showing the interaction between learners(viz., first generation learners and second generation learners) and gender with respect to perceived social support. 
Interaction effect of learners (viz., first generation learners and second generation learners) and gender was seen in perceived social support. The $\mathrm{X}$-axis shows the learners (i.e. first generation learners and second generation learners); the Y-axis shows the Marginal Means of perceived social support, blue line represents the means of boys; and the green line represents the means of girls. The graph shows perceived social support is higher in the first generation girls than second generation girls. Similarly, it showed that second generation boys are higher than first generation boys with respect to perceived social support.

In addition Table 1 indicated significant interaction between learners(viz., first generation learners and second generation learners) and gender with respect to educational aspirations $(\mathrm{F}=7.85, \mathrm{p}<0.01)$. The graphical representation of this result is seen in figure 2 given below.

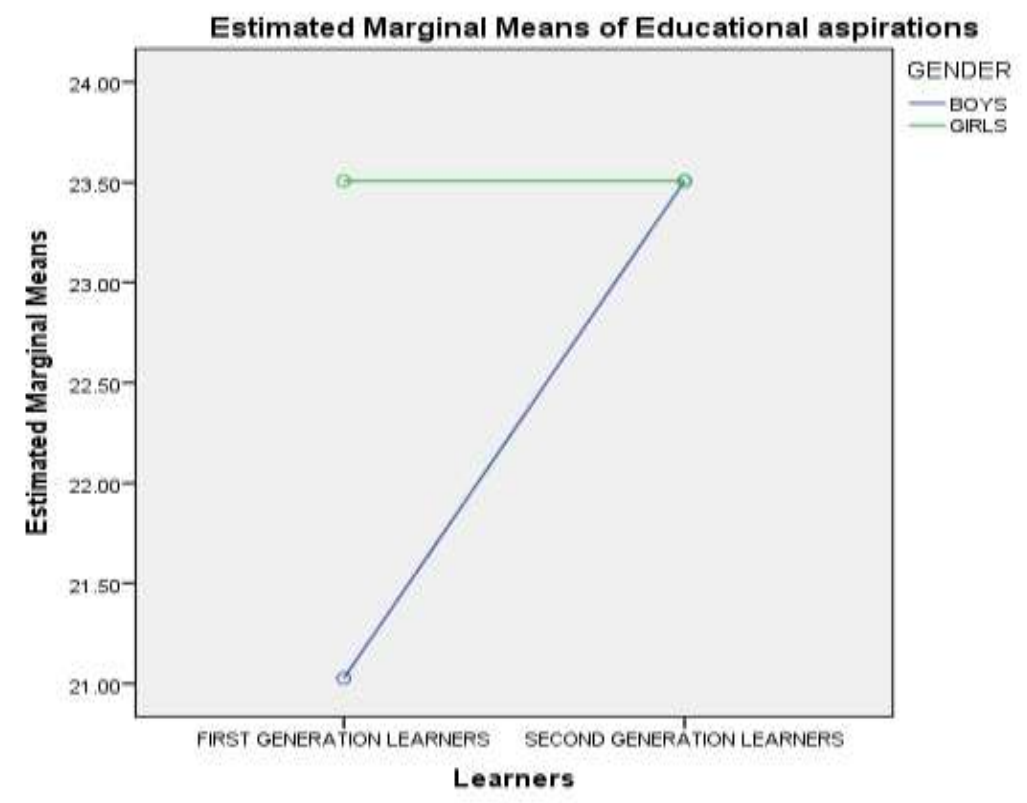

Figure 2 - Line graph showing the interaction between learners (viz., first generation learners and second generation learners) and gender with respect to educational aspirations.

Interaction effect of learners (viz., first generation learners and second generation learners) and gender was seen in educational aspirations. The $\mathrm{X}$-axis shows the learners (i.e. first generation learners and second generation learners); the Y-axis shows the Marginal Means of educational aspirations, blue line represents the means of boys; and the green line represents the means of girls. The graph shows educational aspirations is equal among first generation girls, second generation girls and second generation boys than first generation boys.

Moreover, table 1 also indicated significant interaction between learners(viz., first generation learners and second generation learners) and gender with respect to student school engagement $(\mathrm{F}=18.672, \mathrm{p}<0.001)$. The graphical representation of this result is seen in figure 3 given below. 


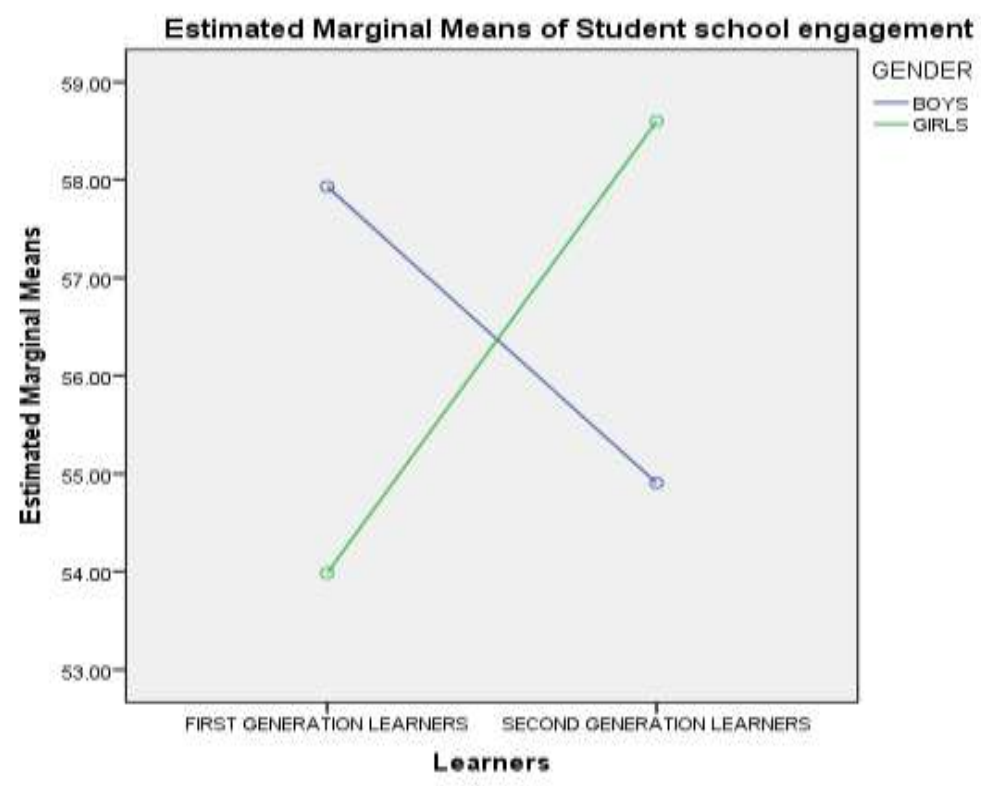

Figure 3 - Line graph showing the interaction between learners (viz., first generation learners and second generation learners) and gender with respect to student school engagement.

Interaction effect of learners (viz., first generation learners and second generation learners) and gender was seen in student school engagement. The $\mathrm{X}$-axis shows the learners (i.e. first generation learners and second generation learners); the Y-axis shows the Marginal Means of student school engagement, blue line represents the means of boys; and the green line represents the means of girls. The graph showed that student school engagement is higher in the first generation girls than second generation girls. Similarly it showed that first generation boys are higher than second generation boys with respect to student school engagement.

Furthermore ,table 1 also revealed significant interaction between learners(viz., first generation learners and second generation learners) and gender with respect to behavioural engagement $(\mathrm{F}=19.137, \mathrm{p}<0.001)$. The graphical representation of this result is seen in figure 4 given below.

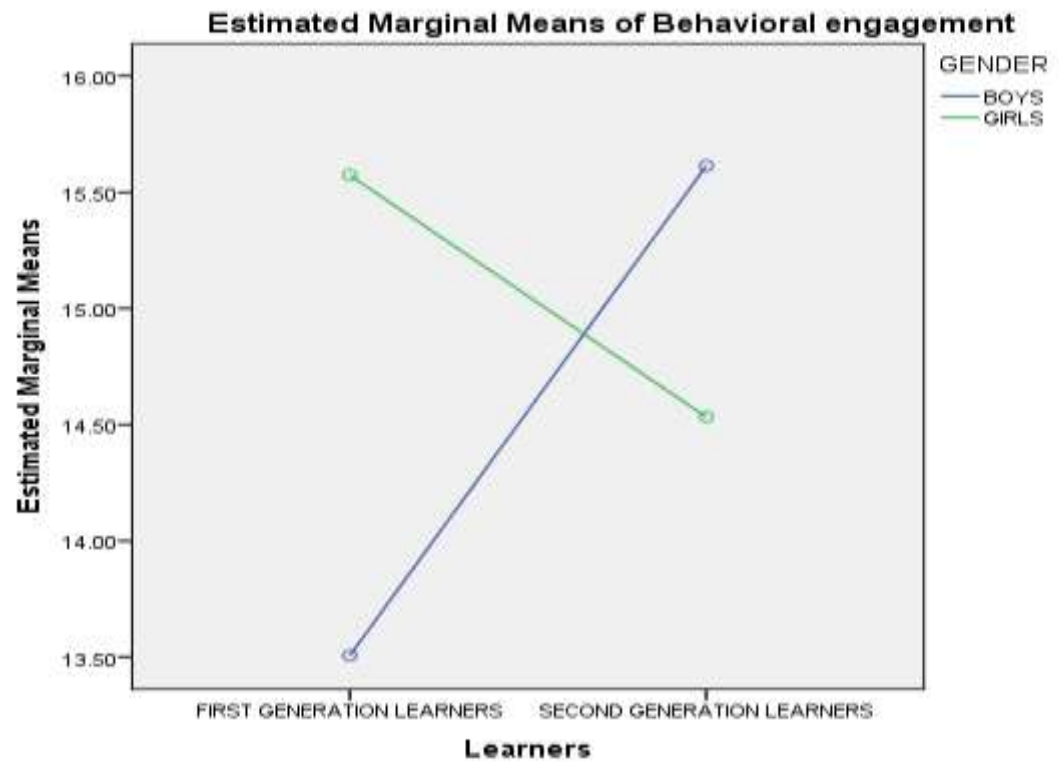

Figure 4- Line graph showing the interaction between learners (viz., first generation learners and second generation learners) and gender with respect to behavioural engagement. 
Interaction effect of learners (viz., first generation learners and second generation learners) and gender was seen in behavioural engagement. The $\mathrm{X}$-axis shows the learners (i.e. first generation learners and second generation learners); the Y-axis shows the Marginal Means of behavioural engagement, blue line represents the means of boys; and the green line represents the means of girls. The graph shows that second generation girls are higher than first generation girls with respect to behavioural engagement. Similarly it showed that second generation boys are higher than first generation boys with respect to behavioural engagement.

Lastly ,table 1 also showed significant interaction between learners(viz., first generation learners and second generation learners) and gender with respect to emotional engagement $(F=23.325, \mathrm{p}<0.001)$. The graphical representation of this result is seen in figure 5 given below.

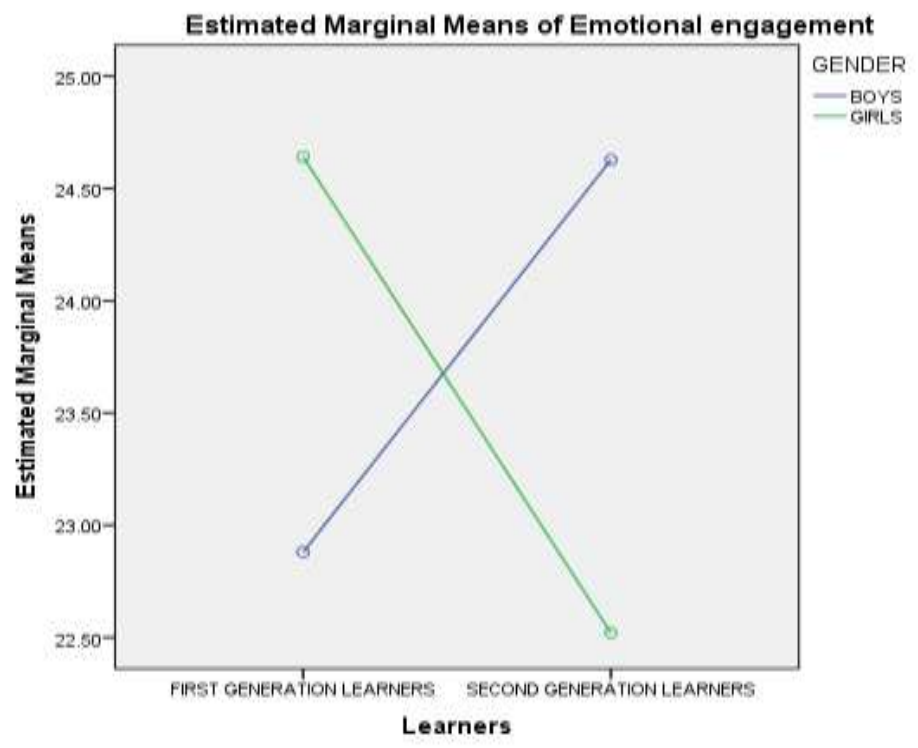

Figure 5- Line graph showing the interaction between learners (viz., first generation learners and second generation learners) and gender with respect to emotional engagement.

Interaction effect of learners (viz., first generation learners and second generation learners) and gender was seen in emotional engagement. The $\mathrm{X}$-axis shows the learners (i.e. first generation learners and second generation learners); the Y-axis shows the Marginal Means of emotional engagement, blue line represents the means of boys; and the green line represents the means of girls. The graph shows that first generation girls are higher than second generation girls with respect to emotional engagement. Similarly it showed that second generation boys are higher than first generation boys with respect to emotional engagement.

As it is evident from table 1 no significant interaction effects of learners (viz., first and second generation learners)and gender on appraisal support ,tangible assets support, belonging support, career aspiration, achievement aspiration, leadership aspiration and cognitive engagement.

Table 2 - Showing the summary of stepwise regression analysis showing the predictors of Student school engagement and its dimensions in first generation learners

First generation learners

Student school Behavioural Emotional Cognitive

Variables

engagement engagement engagement

engagement

\begin{tabular}{ccccc}
\hline Perceived social support & N.S & N.S & N.S & N.S \\
Appraisal support & $\mathbf{0 . 2 9 * * *}$ & $\mathbf{0 . 1 6 *}$ & $\mathbf{0 . 3 5 * * *}$ & $\mathbf{0 . 3 0 * * *}$ \\
& & \\
\hline & 103 \\
\hline
\end{tabular}




\begin{tabular}{ccccc} 
Tangible assets support & N.S & N.S & N.S & N.S \\
Belonging support & N.S & N.S & N.S & $\mathbf{0 . 1 6}^{*}$ \\
Career aspiration & N.S & N.S & N.S & N.S \\
Educational aspiration & $\mathbf{0 . 4 4 * * *}$ & $\mathbf{0 . 3 5}^{* * *}$ & $\mathbf{0 . 2 7} * * *$ & $\mathbf{0 . 2 5}^{* * *}$ \\
Achievement aspiration & N.S & N.S & N.S & $\mathbf{0 . 2 5}^{* * *}$ \\
Leadership aspiration & N.S & N.S & N.S & N.S \\
\hline Perceived social support & N.S & N.S & N.S & N.S \\
Appraisal support & $\mathbf{0 . 0 8 * * *}$ & $\mathbf{0 . 0 2 *}$ & $\mathbf{0 . 1 2} * * *$ & $\mathbf{0 . 0 3}^{* * *}$ \\
Tangible assets support & N.S & N.S & N.S & N.S \\
Belonging support & N.S & N.S & N.S & $\mathbf{0 . 0 2 *}$ \\
Career aspiration & N.S & N.S & N.S & N.S \\
Educational aspiration & $\mathbf{0 . 2 0 * *}$ & $\mathbf{0 . 1 2 * * *}$ & $\mathbf{0 . 0 7 * * *}$ & $\mathbf{0 . 0 6 * * *}$ \\
Achievement aspiration & N.S & N.S & N.S & $\mathbf{0 . 0 6 * * *}$ \\
Leadership aspiration & N.S & N.S & N.S & N.S \\
\hline Total Adjusted R & & & 0.186 & 0.158 \\
\hline $\mathrm{R}^{2}$ & 0.14 & 0.14 & & \\
\hline
\end{tabular}

${ }^{*} \mathrm{p}<0.05,{ }^{* *} \mathrm{p}<0.01,{ }^{* * *} \mathrm{p}<0.001, \Delta \mathrm{R}^{2}$-Change in $\mathrm{R}$ squared, $\beta$-Standardized Beta Coefficient, $\mathrm{N}=150$.

Table 2 specifies regression analysis of predictors of student school engagement (viz., behavioural engagement, emotional engagement and cognitive engagement) in first generation learners. It revealed that student school engagement, behavioural engagement, emotional engagement and cognitive engagement were predicted by appraisal support and educational aspiration. It also showed that cognitive engagement was predicted by achievement aspiration. These results are given in details in Table 3- Table 6.

Table 3 - Stepwise regression analysis showing model predicting student school engagement in first generation learners (75 girls and 75boys)

$\Delta \mathrm{R}^{2} \quad \beta$

Criterion : Student school engagement

\section{Model 1}

1. Educational aspirations

0.20

$0.44 * * *$

Model 2

1 Educational aspirations

0.08

$0.40 * * *$

2. Appraisal support

$0.29 * * *$

Total Adjusted R ${ }^{2}$

0.14 
${ }^{*} \mathrm{p}<0.05,{ }^{* *} \mathrm{p}<0.01,{ }^{* * *} \mathrm{p}<0.001, \Delta \mathrm{R}^{2}$-Change in R squared, $\beta$-Standardized Beta Coefficient, $\mathrm{N}=150$

Table 3 indicated regression analysis to show the predictors of student school engagement in first generation learners. The contribution of educational aspirations in predicting student school engagement was $20 \%$. Appraisal support was another predictor of student school engagement and its contribution in predicting student school engagement was $8 \%$. The positive $\beta$ value of educational aspirations shows a positive correlation with student school engagement $(\beta=0.44)$. Similarly, positive $\beta$ value of appraisal support, shows a positive correlation with student school engagement $(\beta=0.29)$.Educational aspirations and appraisal support together contribute $14 \%$ of the overall variance in student school engagement in first generation learners.

Table 4 - Stepwise regression analysis showing model predicting Behavioural engagement in first generation learners (75 girls and 75boys)

$\Delta \mathrm{R}^{2} \quad \beta$

Criterion: Behavioural engagement

\section{Model 1}

1. Educational aspiration

0.12

$0.35 * * *$

Model 2

1. Educational aspiration

2. Appraisal support

Total Adjusted $\mathrm{R}^{2}$
$0.02 \quad \mathbf{0 . 3 3} * * *$

$0.16 *$

$* \mathrm{p}<0.05, * * \overline{\mathrm{p}}<0.01, * * * \mathrm{p}<0.001, \mathrm{R}$-Coefficient of Correlation, $\Delta \mathrm{R}^{2}$-Change in $\mathrm{R}$ squared, $\beta$-Standardized Beta Coefficient, $\mathrm{N}=150$

Table 4 revealed regression analysis to show the predictors of behavioural engagement in first generation learners. The contribution of educational aspirations in predicting behavioural engagement is $12 \%$. Appraisal support, was another predictor of behavioural engagement and its contribution in predicting behavioural engagement is $2 \%$. The positive $\beta$ value of educational aspirations shows a positive correlation with behavioural engagement ( $\beta=$ 0.35 ). Similarly, positive $\beta$ value of appraisal support, shows a positive correlation with behavioural engagement $(\beta=$ 0.16). Educational aspirations and appraisal support together contribute $14 \%$ of the overall variance in behavioural engagement in first generation learners.

Table 5- Stepwise regression analysis showing model predicting emotional engagement in first generation learners (75 girls and 75 boys)

$\Delta \mathrm{R}^{2} \quad \beta$

Criterion :Emotional engagement

\section{Model 1}

1. Appraisal support

0.12

$0.35 * * *$

Model 2

1. Appraisal support

0.07

$0.30 * * *$ 
2. Educational aspiration

Total Adjusted R
$0.27 * * *$

0.18

$* \mathrm{p}<0.05, * * \mathrm{p}<0.01, * * * \mathrm{p}<0.001, \mathrm{R}$-Coefficient of Correlation, $\Delta \mathrm{R}^{2}$-Change in $\mathrm{R}$ squared, $\beta$-Standardized Beta Coefficient, $\mathrm{N}=150$

Table 5 indicated regression analysis to show the predictors of student school engagement in first generation learners. The contribution of educational aspirations in predicting emotional engagement is $12 \%$. Appraisal support was another predictor of emotional engagement and its contribution in predicting emotional engagement is $7 \%$. The positive $\beta$ value of educational aspirations shows a positive correlation with emotional engagement $(\beta=0.35)$. Similarly, positive $\beta$ value of appraisal support, shows a positive correlation with emotional engagement $(\beta=0.27)$. Educational aspirations and appraisal support together contribute $18 \%$ of the overall variance in emotional engagement in first generation learners.

Table 6 - Stepwise regression analysis showing model predicting cognitive engagement in first generation learners (75 girls and 75boys)

$\Delta \mathrm{R}^{2} \quad \beta$

Criterion: Cognitive engagement

\section{Model 1}

1. Educational aspiration

Model 2

1. Educational aspiration

2. Achievement aspiration

0.06

$0.32 * * *$

$-0.25^{* *}$

Model 3

1. Educational aspiration

2. Achievement aspiration

3.Appraisal support

Model 4

1. Educational aspiration

0.02

$0.30 * * *$

2. Achievement aspiration

3.Appraisal support

0.03

0.30 ***

0.18*

4.Belonging support

Total Adjusted $\mathrm{R}^{2}$
$-0.25^{* *}$

0.20 **

$-0.16 *$

${ }^{*} \mathrm{p}<0.05, * * \mathrm{p}<0.01, * * * \mathrm{p}<0.001$, R-Coefficient of Correlation, $\Delta \mathrm{R}^{2}$-Change in $\mathrm{R}$ squared, $\beta$-Standardized Beta Coefficient, $\mathrm{N}=150$

Table 6 showed regression analysis to show the predictors of cognitive engagement in first generation learners. The contribution of educational aspirations in predicting cognitive engagement is $6 \%$. Achievement aspirations were another predictor of cognitive engagement and its contribution in predicting cognitive engagement 
is 6\%. Appraisal support is also a predictor of cognitive engagement and its contribution to it is $3 \%$.Similarly belonging support, is also a predictor of cognitive engagement and its contribution to it is $2 \%$.

The positive $\beta$ value of educational aspirations shows a positive correlation with cognitive engagement $(\beta=$ 0.25 ). The negative $\beta$ value of achievement aspirations shows a negative correlation with cognitive engagement $(\beta=$ -0.25) . Similarly, positive $\beta$ value of appraisal support, shows a positive correlation with cognitive engagement $(\beta=$ $0.18)$. The negative $\beta$ value of belonging support shows a negative correlation with cognitive engagement $(\beta=-$ 0.16).Educational aspirations, achievement aspiration, appraisal support and belonging support together contribute $15 \%$ of the overall variance in cognitive engagement in first generation learners .

Table 7- Showing the summary of stepwise regression analysis showing the predictors of Student school engagement and its dimensions in second generation learners

Second generation learners

\begin{tabular}{|c|c|c|c|}
\hline & $\begin{array}{c}\text { Student school } \\
\text { engagement }\end{array}$ & $\begin{array}{l}\text { Behavioural } \\
\text { engagement }\end{array}$ & $\begin{array}{l}\text { Emotional } \\
\text { engagement }\end{array}$ \\
\hline
\end{tabular}

\begin{tabular}{|c|c|c|c|c|c|}
\hline & Perceived social support & N.S & N.S & N.S & N.S \\
\hline & Appraisal support & $0.33^{* * *}$ & $0.16 *$ & $0.21 * * *$ & N.S \\
\hline & Tangible assets support & $-0.21 *$ & N.S & N.S & N.S \\
\hline & Belonging support & N.S & N.S & N.S & N.S \\
\hline & Career aspiration & N.S & N.S & N.S & N.S \\
\hline & Educational aspiration & $0.35 * * *$ & $0.35 * * *$ & $0.28 * * *$ & N.S \\
\hline & Achievement aspiration & N.S & N.S & N.S & N.S \\
\hline \multirow[t]{8}{*}{$\beta$} & Leadership aspiration & N.S & N.S & N.S & N.S \\
\hline & Perceived social support & N.S & N.S & N.S & N.S \\
\hline & Appraisal support & $0.03 * * *$ & $0.02 *$ & $0.04 * * *$ & N.S \\
\hline & Tangible assets support & N.S & N.S & N.S & N.S \\
\hline & Belonging support & N.S & N.S & N.S & N.S \\
\hline & Career aspiration & N.S & N.S & N.S & N.S \\
\hline & Educational aspiration & $0.12^{* * *}$ & $0.12 * * *$ & $0.08 * * *$ & N.S \\
\hline & Achievement aspiration & N.S & N.S & N.S & N.S \\
\hline \multirow[t]{2}{*}{$\Delta \mathrm{R}^{2}$} & Leadership aspiration & N.S & N.S & N.S & N.S \\
\hline & Total Adjusted $\mathrm{R}^{2}$ & 0.15 & 0.15 & 0.154 & - \\
\hline
\end{tabular}

${ }^{*} \mathrm{p}<0.05,{ }^{* *} \mathrm{p}<0.01,{ }^{* * *} \mathrm{p}<0.001, \Delta \mathrm{R}^{2}$-Change in $\mathrm{R}$ squared, $\beta$-Standardized Beta Coefficient, $\mathrm{N}=150$. 
Table 7 specifies regression analysis of predictors of student school engagement (viz., behavioural engagement, emotional engagement and cognitive engagement) in second generation learners. It revealed that student school engagement, behavioural engagement and emotional engagement were predicted by appraisal support and educational aspiration. These results are given in details in Table 8- Table 10.

Table 8-Stepwise regression analysis showing model predicting Student school engagement in second generation learners (75 girls and 75boys)

$\Delta \mathrm{R}^{2} \quad \beta$

Criterion :Student school engagement

\section{Model 1}

1. Educational aspirations

Model 2

1 Educational aspirations

2. Appraisal support

Total Adjusted R²
0.12

0.03

$0.19 * * *$

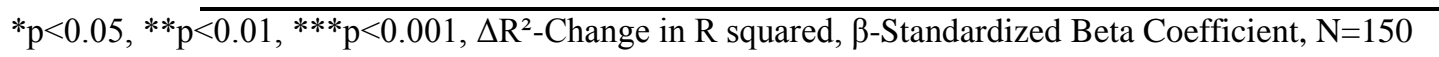

Table 8 indicated regression analysis to show the predictors of student school engagement in first generation learners. The contribution of educational aspirations in predicting student school engagement is $12 \%$. Appraisal support, was another predictor of student school engagement and its contribution in predicting student school engagement is $3 \%$. The positive $\beta$ value of educational aspirations shows a positive correlation with student school engagement $(\beta=0.35)$. Similarly, positive $\beta$ value of appraisal support shows a positive correlation with student school engagement $(\beta=0.19)$. Educational aspirations and appraisal support together contribute $15 \%$ of the overall variance in student school engagement in second generation learners.

Table 9- Stepwise regression analysis showing model predicting Behavioural engagement in second generation learners (75 girls and 75boys)

$\Delta \mathrm{R}^{2} \quad \beta$

Criterion: Behavioural engagement

\section{Model 1}

1. Educational aspirations

0.12

$0.35 * * *$

Model 2

1 Educational aspirations

0.02

$0.33 * * *$

2. Appraisal support

0.16*

Total Adjusted R²

0.15

$* \mathrm{p}<0.05, * * \mathrm{p}<0.01, * * * \mathrm{p}<0.001, \mathrm{R}$-Coefficient of Correlation, $\Delta \mathrm{R}^{2}$-Change in $\mathrm{R}$ squared, $\beta$-Standardized Beta Coefficient, $\mathrm{N}=150$ 
Table 9 revealed regression analysis to show the predictors of behavioural engagement in first generation learners. The contribution of educational aspirations in predicting behavioural engagement is $12 \%$. Appraisal support, was another predictor of behavioural engagement and its contribution in predicting Behavioural engagement is $2 \%$. The positive $\beta$ value of educational aspirations shows a positive correlation with behavioural engagement ( $\beta=0.35)$. Similarly, positive $\beta$ value of appraisal support, shows a positive correlation with behavioural engagement $(\beta=0.16)$. Educational aspirations and appraisal support together contribute $15 \%$ of the overall variance in behavioural engagement in second generation learners.

Table 10 - Stepwise regression analysis showing model predicting Emotional engagement in second generation learners (75 girls and 75boys)

$\Delta \mathrm{R}^{2} \quad \beta$

Criterion: Emotional engagement

Model 1

1. Educational aspirations

0.08

$0.28 * * *$

Model 2

1 Educational aspirations

2. Appraisal support

Total Adjusted R ${ }^{2}$
0.04

$0.26 * *$

$0.21 * *$

$* \mathrm{p}<0.05, * * \mathrm{p}<0.01, * * * \mathrm{p}<0.001$, R-Coefficient of Correlation, $\Delta \mathrm{R}^{2}$-Change in $\mathrm{R}$ squared, $\beta$-Standardized Beta Coefficient, $\mathrm{N}=150$

Table 10 showed regression analysis to show the predictors of emotional engagement in first generation learners. The contribution of educational aspirations in predicting emotional engagement is $8 \%$. Appraisal support, a dimension of Affect was another predictor of emotional engagement and its contribution in predicting emotional engagement is $4 \%$. The positive $\beta$ value of educational aspirations shows a positive correlation with emotional engagement $(\beta=0.28)$. Similarly, positive $\beta$ value of appraisal support, shows a positive correlation with emotional engagement $(\beta=0.21)$. Educational aspirations and appraisal support together contribute $15 \%$ of the overall variance in emotional engagement in second generation learners.

\section{DISCUSSION}

The present study indicated significant difference between first generation learners and second generation learners with respect to career aspiration and its two dimensions i.e educational aspiration and leadership aspiration. These results can be supported by a study conducted by Bowman et al.,(1991) which stated that first generation students have, lower career aspirations. Furthermore, Terenzini and his colleagues (1996), found that first-generation students had lower educational aspirations than their second-generation counterparts did. In another study firstgeneration college students have been found to have lower educational aspirations than continuing-generation college students (Bui, 2002; Terenzini, Springer, Yaeger, Pascarella, \& Nora, 1996).

Moreover, gender difference was found among two dimensions that is with respect to belonging support a dimension of perceived social support and it's supported by a study conducted by Newman and Lohman et al. (2007) which stated that girls reported a higher sense of peer group belonging than boys. Similarly, gender difference was also found in educational aspiration and one possible source of these gender gaps in academic performance is gender-specific attitudes towards and aspirations for education (Buchmann et al., 2008). This is also supported by a study conducted by Mark and Taylor et al. (2013) which stated that boys are more responsive than girls to positive parental characteristics, while educational attitudes and aspirations of boys deteriorate at a younger 
age than those of girls. There is widespread evidence that girls have higher educational aspirations than boys (Schoon et al., 2007). They are, for example, more likely than boys to want to remain in post-compulsory education and less likely to want to leave education and enter full-time work at age 16 (Willitts et al., 2005). Research suggests that boys from low socioeconomic status families and from minority ethnic backgrounds have particularly low aspirations (Burke 2006). Previous research on gender-related educational aspirations using rural samples has found that girls maintain higher educational aspirations than male students (Elder \& Conder, 2000; Lapan, Kim \& Koscuilek, 2003).

Furthermore, interaction effect was shown with respect to perceived social support, educational aspiration, student school engagement and its two dimension behavioural engagement and emotional engagement. A study conducted by Jenkins, Sharon Rae, Belanger, Aimee et al., (2013) reported that first -generation participants have less social support from family and friends, more single-event traumatic stress, less life satisfaction, and marginally more depression symptomatology than non-first-generation participants, but significant generation-gender interactions showed first-generation women doing worse and first-generation men doing better than others. There is evidence with respect to interaction among generational status and gender in school engagement as it is revealed that many college students are unfortunately not aware of the resources available to them, especially first-generation female students. National Survey of Student Engagement (2005) in Colorado found that between 40 and 50 percent of first-year students never used career services, financial advising, or academic tutoring services. In some cases, First generation female students do not understand the struggle of adjusting to college until it is too late. As a result, about $43 \%$ of first generation students drop out of college before their second year, whereas about $20 \%$ of traditional students leave college without a degree (McKay, 2008).

A Study on 'Education of First Generation Girl Students in Senior Intermediate Colleges in Telangana found that first generation girl students have certain issues such as, education was not free even in government schools, they were earning wages through paid work, ill health was a cause for irregular attendance, issue of marriage, gender discrimination by school teachers, and domestic violence meted out by fathers who have surrendered themselves to alcoholism etc. (M.V foundation, 2016). These issues can be major causes that can affect educational life, mental health, emotional health etc., which, in turn, can affect their perceived social support, career aspirations and student school engagement.

The present study also revealed that appraisal support dimension of perceived social support was found to be a predictor of students' school engagement and its dimensions (behavioural engagement, emotional engagement and cognitive engagement) and belonging support a dimension of perceived social support was found to be a predictor of cognitive engagement among first generation learners. Among second generation learners appraisal support dimension of perceived social support was found to be a predictor of school engagement and its dimensions (behavioural engagement \& emotional engagement) and tangible assets support a dimension of perceived social support was found to be predictor of students' school engagement.

The dimension appraisal support as a predictor in both first and second generation learners can be supported by various studies for example; Fredricks et al., (2004)stated that support from the teacher, or good teacher-student relationships, is the most effective factor predictor of all school engagement dimensions. However, the engagement tends to develop reciprocally: teachers may have more negative attitudes towards these lowengagement students, which again makes them less and less engaged. On the contrary, the engaged students increase their engagement via positive reinforcement from their teachers (Klem \& Connell, 2004; Skinner \& Belmont, 1993).

Belonging support as a predictor of cognitive engagement dimension of students school engagement can be supported by a study conducted by Osterman (2000) which reveals that students who experience a sense of belonging in educational environments are more motivated, more engaged in school and classroom activities, and more dedicated to school.

Tangible assets support a dimension of perceived social support can be supported as a predictor of students school engagement with a study of the PASS Program (Promoting Achievement in School through Sport) by McClendon, Nettles \& Wigfield (2000) in which the PASS model provided the framework for teachers that encouraged them to provide emotional and tangible support, to set high expectations and engage students in the learning process. Kumar (2015) conducted a study on secondary school students of Kerala and revealed that Parent Support, Teacher Support and Peer Support is found to be effective for predicting School Engagement. Thus the study emphasizes the role of Social Support in the development of an individual. The behavioural, cognitive and emotional development of a child in the school is mainly associated with the support he/she perceives from the parent, teacher and the peers. 
A better parental support that the child perceives improves the behaviour of the child in the school. The teacher support and peer support increases student's engagement in the school. The current study highlighted that, among first generation learners educational aspiration dimension of career aspiration was found to be a predictor of student's school engagement and its dimensions (behavioral engagement, emotional engagement \& cognitive engagement) and achievement aspiration a dimension of students school engagement was found to be a predictor of cognitive engagement. Among second generation educational aspiration dimension of career aspiration was found to be a predictor of student's school engagement and its dimensions (behavioural engagement \& emotional engagement). In a study Hill and Wang (2015) revealed that aspirations are key to engagement; when connected to aspirations, engagement in school becomes self-motivating. The connection between aspiration and school engagement is also important for students who are already high achievers. Students' engagement with school has been found to be an important factor in students' school success (Fredricks et al., 2004; Kortering \& Braziel, 2008) and adolescent well-being (Archambault et al., 2009). Engagement with school may also lead to enhanced psychosocial engagement across the lifespan in multiple settings (Furlong et al., 2003). Because engagement facilitates academic and social learning, school engagement is a relevant construct for all students (Furlong \& Christenson, 2008). However, understanding students' engagement with school has been primarily motivated by a desire to increase academic achievement and high school graduation rates (Appleton et al., 2008; Fredricks et al., 2011). The high school graduation rate has not changed significantly over the past 30 years (Dynarski et al., 2008). Approximately 75\% of ninth graders will graduate from high school with their cohort (Aud et al., 2011), and almost $4 \%$ of students drop out of high school each year (Chapman, Laird, \& Ramani, 2010).

Schools and Colleges need to recognize that first-generation students do not easily come forward to seek help. Investigation of cultural aspects on academic performance of first generation students can help in taking measures to avoid the impact of such factors. Assess the effect of specific academic major programs on first generation students' performance. Assess which leadership style the teachers possess (autocratic, democratic, instructional etc.) because leadership style play great role on the members under the guidance of the leader.

Admissions officers could design presentations specifically for first-generation students that emphasize the behaviours common to successful first-generation students who have completed education .To raise educational aspirations, institutions could work with local schools. Colleges and universities have the ability to redesign their institutional cultures, teaching practices and academic support services to be more inclusive of first-generation college students. For instance, they can offer required courses in a variety of different formats (hybrid, on-line, faceto-face) and timings (between semesters, during summers) to help first generation students reduce degree completion time and save money. They can recruit former first-generation faculty members to advice and mentor students. A web page for first-generation students and families can be created that features success stories, userfriendly financial aid as well as scholarship information, and links to other opportunities. With the right support from institutions of higher education, first-generation students can earn their degree, reinvent themselves and reposition their families in positive ways for generations to come. Workshops for advisors and others who may work closely with first-generation students should address issues that may be particularly relevant to this group; at the least, advisors should know who among their advisees are the first in their family to go to school /college and should discuss on multiple occasions how students can get involved in activities inside and outside the classroom that will increase their overall level of engagement with learning resources and that will promote greater social and academic integration.

\section{REFERENCES}

1. Appleton, J.J., Christenson, S.L., \& Furlong, M.J. (2008). Student engagement with school: Critical conceptual and methodological issues of the construct. Psychology in the Schools, 45, 369-386.

2. Aud, S., Hussar, W., Kena, G., Bianco, K., Frohlich, L., Kemp, J., \&Tahan, K. (2011). The Condition of Education 2011 (NCES 2011-033). U.S. Department of Education, National Center for Education Statistics. Washington, DC: U.S. Government Printing Office.

3. Awasthy, G. \& Khimani, V. Academic challenges faced by first generation learners in an NGO- run school vis-a-vis Government School in the Nainital District (Uttarakhand) of Northern India. Submitted for fulfilment of introduction to research course, Azim Premji University, Bangalore (2015).

4. Bandura (2001).Self- efficacy beliefs as shapers of children's aspirations and career trajectories. Child development, 72(1), 187-206. 
5. Buchmann, C., DiPrete, T. A., \& McDaniel, A. (2008).Gender inequalities in education.Annual Review of Sociology, 34, 319-337.

6. Burke, P. J. 2006. "Men Accessing Education: Gendered Aspirations." British Educational Research Journal, 32(5), 719-33.

7. Connell, J. P., \& Wellborn, J. G. (1991). Competence, autonomy, and relatedness: A motivational analysis of self-system processes. In M. R. Gunnar \& L. A. Sroufe (Eds.), Self-processes and development: Minnesota symposium on child psychology (Vol. 23, pp. 43-77). Chicago: University of Chicago Press.

8. Csikszentmihalyi, M. (1990). Flow: The psychology of optimal experience. New York: Harper Perennial

9. Dynarski, M., Clarke, L., Cobb, B., Finn, J., Rumberger, R., and Smink, J. (2008). Dropout Prevention: A Practice Guide (NCEE 2008-4025). Washington, DC: National Center for Education Evaluation and Regional Assistance, Institute of Education Sciences, U.S. Department of Education

10. Elder, G. H., \& Conger, R. D. (2000). Children of the land: Adversity and success in rural America. Chicago: University of Chicago Press.

11. Finlay, K. A. (2006). Quantifying school engagement: Research report.National Center for School Engagement. Denver, CO.

12. Finn, J. D., Pannozzo, G .M., \&V oelkl, K. E. (1995). Disruptive and inattentive-withdrawn behavior and achievement among fourth graders. Elementary School Journal, 95, 421- 454.

13. Fredericks, J.A., Blumenfeld, P., Friedel, J., \& Paris, A. (2005).School engagement. In K.A. Moore \& L. Lippman (Eds.), What do children need to flourish?: Conceptualizing and measuring indicators of positive development. New York, NY: Springer Science and Business Media.

14. Fredricks J.A., Blumenfeld P.C., Paris A.H. (2004) School engagement: Potential of the concept, state of the evidence. Review of Educational Research; 74:59-109.

15. Fredricks, J. A., Blumenfeld, P., Friedel, J., \& Paris, A. (2003). Paper presented at the Indicators of Positive Development Conference, Child Trends, March 11th-13 ${ }^{\text {th }}$

16. Fredricks, J., McColskey, W., Meli, J., Montrosse, B., Mordica, J., \& Mooney, K. (2011). Measuring student engagement in upper elementary through high school: A description of 21 instruments. Greensboro, NC: Regional Educational Laboratory Southeast.

17. Furlong, M. J. \& Christenson, S. L. (2008). Engaging students at school and with learning: A relevant construct for all students. Psychology in the Schools, 45, 365-368.

18. Furlong, M. J., Whipple, A. D., St. Jean, G., Simental, J., Soliz, A., \&Punthuna, S. (2003). Multiple contexts of school engagement: Moving toward a unifying frame work for educational research and practice. California School Psychologist, 8,99-114

19. Handley, S. M. (2004). Perceived social support in young adults with cancer and the camp experience (Doctoral dissertation, Montana State University-Bozeman, College of Nursing).

20. Horn, L., \& Nuñez, A. M. (2000). Mapping the road to college first-generation students' math track, planning strategies, and context of support. Diane Publishing.

21. Covell, K., MacIntyre, P. D., \& Wall, J. (1999).Implications of social supports for adolescents' education and career aspirations. Canadian Journal of Behavioural Science, 31(2), 63.

22. Jenkins, S. R., Belanger, A., Connally, M. L., Boals, A., \&Durón, K. M. (2013).First- generation undergraduate students' social support, depression, and life satisfaction. Journal of College Counseling, 16(2), 129-142.

23. Kim, Y. H. (2014). Measuring Career Aspirations in Korean College Women (Doctoral dissertation).

24. Klem, A. M., \& Connell, J. P. (2004). Relationships matter: Linking teacher support to student engagement and achievement. Journal of School Health, 74(7), 262-273.

25. Laird, J., Cataldi, E. F., Kewal-Ramani, A., \& Chapman, C. (2008).Implementing Graduation counts: State progress to date. Washington, DC: National Center for Education Statistics, Institute of Education Sciences, U.S. Department of Education

26. McClendon, C., Nettles, S. M., \& Wigfield, A. (in press). Fostering resilience in high school classrooms: A Study of the PASS program (Promoting Achievement in School Through Sport). In M. Sanders (Ed.), Schooling students placed at risk: Research, policy, and practice in the education of poor and minority students. Mahwah, NJ: Lawrence Erlbaum Associates, Inc

27. McKay, V. C. (2008). First-generation student success: The role of faculty interaction in service learning courses. Communication Education, 57(3), 356-372.

28. Meece, J., Blumenfeld, P. C., \& Hoyle, R. H. (1988).Students' goal orientation and cognitive engagement in classroom activities. Journal of Educational Psychology, 80, 514-523.

29. Newman, B. M., Lohman, B. J., \& Newman, P. R. (2007). Peer group membership and a sense of 
belonging: Their relationship to adolescent behavior problems. Adolescence, 42(166), 241.

30. Oakes, J. M., and P. H. Rossi. 2003. "The measurement of SES in health research: current practice and steps toward a new approach." SocSci Med 56(4):769-84.

31. Osterman, K. F. (2000). Students' need for belonging in the school community. Review of Educational Research, 70, 323-367.

32. Penrose, A. M. (2002). Academic literacy perceptions and performance: Comparing first-generation and continuing-generation college students. Research in the Teaching of English, 437-461.

33. Pike, G. \& Kuh, G. (2005). First and second generation college students: A comparison of their engagement and intellectual development. Journal of Higher Education, 76(3): 276-300.

34. Sarason, I.G. , Levine, H.M., Basham, R.B. \& Sarason, B.R. (1983). Assessing Social Support: The Social Support Questionnaire. Journal of Personality and Social Psychology 44: 127-139.

35. Schoon, Ingrid; Andy Ross and Peter Martin. (2007). Science Related Careers: Aspirations and Outcomes in Two British Cohort Studies. Equal Opportunities International, 26(2), 129 -43.

36. Sirin, S. R. Diemer, M. A., Jackson, L. R., Gonsalves, L., \& Howell, A. (2004). Future aspirations of urban adolescents: A person-in-context model. International Journal of Qualitative Studies in Education, 17(3), 437-459

37. Striplin, Jenny J. 1999. Facilitating Transfer for First-Generation Community College Students (ERIC ED430627). ERIC Digest, June.

38. Terenzini, P., Springer, L., Yaeger, P., Pascarella, E., \& Nora, A. (1996). First-Generation College Students: Characteristics, Experiences, and Cognitive Development. Association for Institutional Research. Boston, MA.

39. Terenzini, P., Springer, L., Yaeger, P., Pascarella, E. and Nora, A. 1996. First- generation college students: Characteristics, experiences, and cognitive development. Research in Higher Education, 37(1): 1-22.

40. Thayer, P. B. (2000). Retention of students from first generation and low income backgrounds.The Journal of the Council for Opportunity in Education.U.S. Department of Education.

41. Vanden Bos, G. R. (Ed.). (2007). APA Dictionary of Psychology. Washington, DC: American Psychological Association.

42. Veenhoven, R. (1996). Developments in satisfaction-research. Social Indicators Research, 37(1), 1-46.

43. Veiel, H.O.F. \& Baumann, V. (eds) (1992) The Meaning and Measurement of Social Support. New York: Hemisphere.

44. Veiga, F., Robu, V., Moura, H., Goulão, F., \& Galvão, D. (2014).Students' engagement in school, academic aspirations, and sex. Envolvimento dos Alunosna Escola: Perspetivas Internacionais da Psicologia e Educação/Students' Engagement in School. International Perspectives of Psychology and Education, 348-360.

45. Willitts, M., Anderson, T., Tait, C., \& Williams, G. (2005). Children in Britain: findings from the 2003 Families and Children Study (FACS) (No. 249). A report of research carried out by the National Centre for Social Research and the Department for Work and Pensions.

46. http://timesofindia.indiatimes.com/city/chennai/30-of-new-engineering-students-in-Tamil-Nadu-firstgeneration-college-goers/articleshow/38103397.cms

47. http://www.thehindu.com/opinion/op-ed/dealing-with-first-generation-schoolgoers/article6802551 